\title{
Efektifitas Terapi Rendam Air Hangat dengan Garam terhadap Skala Nyeri Arthritis Pada Lansia Di Panti Sosial Tresna Werdha Budi Luhur Kota Jambi
}

\author{
Mursidah Dewi ${ }^{1 *}$, Sovia ${ }^{2}$, Putri Dwi Adha ${ }^{3}$ \\ 1,2,3 Jurusan Keperawatan Politeknik Kesehatan Kemenkes Jambi \\ "Correspondence email: mursidah.dewi@yahoo.co.id
}

\begin{abstract}
Abstrak. Faktor penuaan karena pertambahan usia seringkali disertai dengan timbulnya berbagai penyakit degeneratif. Penyakit degeneratif yang dominan pada pasien lanjut usia ini berpotensi membutuhkan perawatan jangka panjang (Long-Term Care.)Salah satu yang dominan terjadi adalah Arthritis. Masalah yang sering timbul pada lansia dengan Arthritis adalah nyeri saat beraktifitas, kesemutan, bengkak serta kekakuan pada sendi. Penatalaksanaan Arthritis bisa dilakukan secara farmakologis dan nonfarmakologis, salah satu bentuk non-farmakologis adalah rendam air hangat. Penelitian ini merupakan penelitian kuantitatif, menggunakan pre experimental design dengan non equivalent (pretest dan posttest) two group design, bertujuan untuk mengetahui efektifitas terapi rendam air hangat dan garam terhadap skala nyeri lansia dengan Arthritis. Penelitian ini dilaksanakan di PSTW Budi Luhur Kota Jambi, sampel penelitian berjumlah 30 responden. Hasil penelitian menunjukkan terdapat perbedaan yang signifikan rerata skala nyeri terapi rendam air hangat tambah garam dengan terapi rendam air hangat tanpa garam pada lansia dengan Arthritis ( $\mathrm{p}$-value $0,000<\mathrm{p} \alpha 0,05$ ), lebih lanjut terapi rendam air hangat dengan garam efektif diberikan untuk menurunkan skala nyeri pada lansia dengan Arthritis. Penatalaksanaan non-farmakologis berupa pendidikan kesehatan dapat diberikan pada lansia terkait manajemen nyeri non-farmakologis. Meningkatkan peran perawat sebagai care provider untuk memberikan pelayanan secara holistik dalam melaksanakan tindakan mandiri perawat. Peran edukator untuk memberikan pendidikan kesehatan tentang penatalaksanaan nyeri Arthritis, peran fasilitator dalam memfasilitasi lansia untuk melakukan terapi, peran motivator untuk memberikan semangat pada lansia dalam melakukan terapi, selain ekonomis terapi rendam air hangat dengan garam ini dapat dilakukan secara mandiri, serta peran kolaborator, agar dapat berkolaborasi dengan tim kesehatan lain yang ada di panti dalam penatalaksanaan nyeri Arthritis pada Lansia.
\end{abstract}

Kata kunci: arthritis; terapi rendam air hangat; garam; nyeri; lansia

\begin{abstract}
The aging factor caused by increace of age, often accompanied by various degenerative diseases. The dominant degenerative disease in elderly patients has the potential to require long-term care. One of the dominant occurrences is Arthritis. Problems that often arise in the elderly with arthritis are pain during activity, tingling, swelling and stiffness in the joints. Arthritis management can be done pharmacologically and non-pharmacologically, one form of non-pharmacological is warm water soaking. This research is a quantitative study, using a pre-experimental design with non-equivalent (pretest and posttest) two group design, aims to determine the effect of warm water and salt therapy on the pain scale of the elderly with Arthritis. This research was conducted at PSTW Budi Luhur Jambi, the research sample was 30 respondents. The results showed a significant difference in the mean pain scale of warm water soak therapy plus salt with warm water soak therapy without salt in the elderly with Arthritis ( $p$-value 0,000 $<p \alpha 0,05$ ), furthermore warm water soak therapy with salt was effective given to reduce the pain scale in the elderly with arthritis. Non-pharmacological management in the form of health education can be given to the elderly related to the management of pain. Enhancing the role of nurses as care providers can be done to provide holistic services in implementing nurses' independent actions. The role of educators to provide health education about the management of Arthritis pain, the role of facilitators and motivators in facilitating the elderly and to encourage the elderly to conduct therapy, in addition warm water soak with salt is like economical therapeutic, can be done independently. As well as the nurse can collaborate with other health teams in the institution to manage Arthritis pain in the elderly.
\end{abstract}

Keywords: arthritis; warm water soak therapy; salt; pain; elderly

\section{PENDAHULUAN}

Lanjut Usia (Lansia) merupakan tahap akhir perkembangan pada daur kehidupan manusia (Ekasari, dkk, 2018). Menurut Undang-undang Nomor 13 tahun 1998 tentang kesejahteraan lanjut usia disebutkan lanjut usia adalah seseorang yang mencapai usia 60 tahun ke atas (Dewi, S.R, 2014; Kemenkes, 2016).

Secara global populasi lansia terus mengalami peningkatan, pertumbuhan penduduk lansia diprediksi akan meningkat cepat di masa yang akan datang terutama di negara-negara berkembang. Lansia di
Indonesia mengalami peningkatan yang cukup berarti selama 30 tahun terakhir dengan populasi 5,30 juta jiwa (sekitar 4,48\%) pada tahun 1970, meningkat menjadi 18,10 juta jiwa pada tahun 2010, di tahun 2014 penduduk lansia berjumlah 20,7 juta jiwa (sekitar $8,2 \%$ ) dan diprediksikan jumlah lansia meningkat menjadi 27 juta pada tahun 2020.

Hasil proyeksi penduduk di tahun 2010-2035, Indonesia sebagai salah satu negara berkembang akan mengalami ledakan jumlah penduduk lansia, Indonesia akan memasuki periode lansia (ageing), dimana 
kelompok umur 0-14 tahun dan 15-49 berdasarkan proyeksi 2010-2035 menurun. Kelompok umur lansia (50-64 tahun dan 65+) berdasarkan proyeksi 2010-2035 terus meningkat. $10 \%$ penduduk akan berusia 60 tahun ke atas di tahun 2020 yang berkisar 27 juta jiwa, 33,7 juta jiwa pada tahun 2025 dan 48,2 juta jiwa tahun 2035 . Populasi lansia di Indonesia diprediksi meningkat lebih tinggi dari pada populasi lansia di wilayah Asia dan global setelah tahun 2050 (Kemenkes, 2013; Kemenkes, 2016).

Seiring dengan meningkatnya jumlah lansia di Indonesia, meningkat pula permasalahan penyakit akibat proses penuaan/degenerative. Lansia merupakan kelompok usia yang rentan terhadap kesakitan akibat penurunan fungsi dalam tubuh. Faktor penuaan karena pertambahan usia seringkali disertai dengan timbulnya berbagai penyakit kronis seperti Arthritis, Gangguan Pendengaran, Demensia, Diabetes mellitus, serta masalah jantung dan Hipertensi. Penyakit degeneratif yang dominan pada pasien lanjut usia ini berpotensi membutuhkan perawatan jangka panjang (Long-Term Care)(Anderson, 2007; Anderson, ET \& McFarlane, JM. 2011; Dahlkemper, TR, 2016). Kondisi ini menyebabkan penanganan penyakit pada usia lanjut memerlukan waktu yang lebih lama dan bersifat khusus (Muhith, A \& Siyoto, S. 2016).

Sepuluh masalah kesehatan lanjut usia, dimana masalah terbanyak pada Lanjut Usia adalah Penyakit Tidak Menular (PTM) antara lain Hipertensi, Arthritis, Stroke, Penyakit Paru Obstruktif Kronik (PPOK) dan Diabetes Mellitus (DM). Arthritis merupakan penyakit ke-2 terbanyak setelah Hipertensi. Hasil Riset Kesehatan Dasar (2018) data berdasarkan hasil diagnosis dokter, diketahui prevalensi penyakit sendi di 34 propinsi, didapatkan prevalensi tertinggi adalah propinsi Aceh, dan prevalensi terendah adalah Sulawesi Utara. Propinsi Jambi, menempati urutan ke-7 terbanyak untuk prevalensi penyakit sendi ini (Kemenkes, 2018).

Arthtritis secara umum diartikan sebagai peradangan sendi. Baluni, S (2014) menjelaskan Arthritis adalah suatu bentuk gangguan sendi yang melibatkan peradangan pada satu atau lebih sendi, dengan artritis, area di dalam atau di sekitar sendi menjadi meradang, menyebabkan rasa sakit, kaku dan, kadang-kadang, sulit bergerak. Beberapa jenis radang sendi juga mempengaruhi bagian lain dari tubuh, seperti kulit dan organ dalam lainnya. Pada penyakit peradangan sendi, hampir selalu terdapat gejala nyeri dan kaku terutama pada persendian. Masalah yang sering timbul pada lansia dengan Arthritis adalah nyeri saat beraktifitas, kesemutan, bengkak serta kekakuan pada sendi.

Nyeri didefinisikan sebagai sensasi yang tidak menyenangkan, bersifat subjektif dan berhubungan dengan pancaindera, serta merupakan suatu pengalaman emosional yang dikaitkan dengan kerusakan jaringan baik aktual maupun potensial, digambarkan sebagai suatu kerusakan atau cidera. Nyeri terjadi dalam berbagai derajat keparahan, baik akut maupun kronis. Walaupun tidak menyenangkan, nyeri merupakan bagian komponen utama sistem saraf, menginstruksikan neuron motorik dari sistem saraf pusat sebagai deteksi adanya kerusakan fisik. (Potter \& Perry, 2010; Amudha, 2014, Benita, 2016).

Keluhan terkait gangguan persendian (nyeri) menjadi keluhan utama pada lansia. Pada Arthritis kronis, rasa nyeri akan timbul jika persediannya digerakkan, rasa nyeri ini berbeda dengan rasa nyeri tajam pada penyakit saraf, yang tidak bergantung pada gerakkan (Agoes, 2011).

Tujuan pengobatan Arthritis adalah untuk meredakan rasa sakit, meningkatkan mobilitas dan kekuatan sendi, serta mengendalikan penyakit seefektif mungkin. Penatalaksanaan Arthritis bisa dilakukan secara farmakologis dan non-farmakologis. Pada saat ini, penderita banyak yang meminimalkan penggunaan obatobatan untuk mengurangi nyeri, karena obat-obatan yang dikonsumsi tersebut dapat menyebabkan ketergantungan, memiliki kontraindikasi serta menimbulkan efek samping. Terapi non-farmakologis dapat dilakukan dengan berbagai cara yaitu, edukasi terkait manajemen nyeri secara mandiri bagi penderita Arthritis, relaksasi, meningkatkan intake cairan (air putih), penggunaan pelindung sendi, kompres panas/dingin, rendam hangat, diet dengan cara mengatur pola hidup dan asupan makanan, menjaga ideal tubuh, latihan/berolahraga dan operasi ( Mendelson, McCullough \& Chan, 2010; Soeroso, J \& Algristian, H, 2011; Baluni S, 2014; Mctaggart, 2016; Zelman, 2019).

Rendam air hangat adalah salah satu tindakan yang dilakukan dengan memberikan cairan hangat untuk memenuhi kebutuhan rasa nyaman, mengurangi atau membebaskan nyeri, mengurangi atau mencegah terjadinya spasme otot, dan memberikan rasa hangat (Uliyah \& Hidayat 2008). Rendam merupakan metode relaksasi dengan pemeliharaan suhu tubuh dengan menggunakan cairan atau alat yang dapat menimbulkan hangat atau dingin pada bagian tubuh yang memerlukan dengan tujuan untuk memperlancar sirkulasi darah, dan mengurangi rasa sakit atau nyeri.

Berdasarkan hasil penelitian Suriya, M (2016) tentang Efektifitas Kompres Air Hangat Terhadap Penurunan Nyeri Pada Pasien Asam Urat Di Puskesmas Lubuk Begalung tahun 2016 menunjukkan hasil bahwa pemberian kompres air hangat efektif untuk menurunkan skala nyeri, dengan jumlah rerata penurunan skala nyeri sebesar 1,167. Kompres air hangat termasuk intervensi yang efektif sebagai penghilang rasa nyeri, karena rasa hangat yang diberikan kepada pasien asam urat dapat melancarkan pembuluh darah sehingga dapat menghilangkan rasa nyeri tersebut.

Pemberian kompres air hangat merupakan intervensi keperawatan yang sudah lama di aplikasikan oleh perawat, kompres air hangat dianjurkan untuk 
menurunkan nyeri karena dapat meredakan nyeri, meningkatkan relaksasi otot, meningkatkan sirkulasi, meningkatkan relaksasi psikologis, dan memberi rasa nyaman, bekerja sebagai counteriritan (Kozier, B et al, 2010)

Penambahan garam pada air panas untuk mengatasi nyeri sendi sangat efektif dalam pengobatan nyeri. Garam dapat bersifat topikal dan cepat mengurangi rasa sakit pada persendian. Sebanyak 200 mg garam dicampur dalam air panas, kemudian dilakukan kompres, penyiraman maupun perendaman pada sendi yang sakit selama 20 menit, dilakukan selama tiga kali seminggu. Intervensi ini diketahui sangat efektif untuk meringankan kekakuan pada sendi (Benita, R.F. 2016)

Lebih lanjut, Nuraini (2016) memaparkan rendam larutan air garam hangat dapat mengurangi skala nyeri pada bagian yang terkena Gout Arthritis. Merendam bagian yang terkena Gout Arthritis, darah akan mengalir lebih lancar dan penggumpalan asam urat pada persendian juga akan berkurang. Gout Arthritis memang penyakit yang dapat menghalangi segala macam aktivitas sehari-hari. Berendam dalam air garam ternyata bisa membantu untuk mengatasi nyeri.

Penelitian lain yang dilakukan oleh Nuridayanti (2017) tentang pengaruh rendam air garam terhadap penurunan tingkat nyeri pada penderita Gout di Desa Toyoresmi Kecamatan Gampengrejo Kabupaten Kediri dihasilkan $65 \%$ pasien mengalami penurunan tingkat nyeri dan terdapat pengaruh rendam air garam terhadap penurunan tingkat nyeri pada penderita Gout Arthritis (willcoxon, $\mathrm{p}$ value $0,000<0,05$ ), sehingga ada pengaruh rendam air garam terhadap penurunan tingkat nyeri. Menerapkan rendam air garam dapat dilakukan sebagai salah satu alternatif dalam upaya menurunkan tingkat nyeri.

Hasil observasi dan wawancara secara langsung di PSTW Budi Luhur Kota Jambi diketahui dari lima orang lansia yang menderita Arthritis mengatakan nyeri terasa pada sendi-sendi, sebagian besar pada sendi kaki. Merasa tidak nyaman dengan nyeri yang dirasakan. Hasil pengukuran skala nyeri berada dalam rentang nyeri ringan sampai sedang, untuk mengurangi nyeri lansia biasanya hanya menggunakan balsem atau minyak gosok, dan lansia biasanya meminta obat di klinik yang ada di panti. Berdasarkan hasil pemikiran dan latar belakang diatas maka penatalaksanaan Terapi Rendam Air hangat dengan garam pada lansia yang mengalami Arthritis perlu dilakukan. Oleh karena itu, penulis tertarik untuk melakukan penelitian Efektifitas Terapi Rendam Air hangat dengan garamTerhadap Skala Nyeri pada Lansia dengan Arthritis di Panti Sosial Tresna Werdha Budi Luhur Kota Jambi

\section{METODE}

Penelitian ini merupakan penelitian kuantitatif, menggunakan Pre Experimental Design dengan non equivalent (pretest dan posttest) two group design (Riyanto, 2011). Penelitian ini dilakukan untuk mengetahui pengaruh dua perlakuan berbeda pada dua kelompok lansia dengan Arthritis, dari hasil pengukuran rerata skala nyeri sebelum dan sesudah perlakuan dilakukan. Perlakuan yang dimaksud adalah terapi rendam air hangat dan garam serta terapi rendam air hangat tanpa garam.

Penelitian dilakukan di PSTW Budi Luhur Kota Jambi tahun 2019. Sampel dalam penelitian ini berjumlah 30 orang lansia, yang dibagi menjadi dua kelompok intervensi antara lain kelompok intervensi terapi rendam air hangat dengan garam dan kelompok intervensi terapi rendam air hangat tanpa. Pemilihan kedua kelompok ini tidak dilakukan secara acak, melainkan atas pertimbangan bahwa kedua kelompok memiliki karakteristik yang semirip mungkin (non ekuivalent group).

Pada penelitian ini sampel yang dipilih adalah yang benar-benar memenuhi kriteria inklusi yang telah ditetapkan oleh peneliti sebagai subjek penelitian antara lain; lansia dengan riwayat Arthritis dan sering mengeluh nyeri terutama pada kaki dan sering berobat ke klinik yang ada di PSTW Budi Luhur Kota Jambi. Arikunto (2010) menyatakan semakin mirip karakteristik sampel yang diambil, semakin baik hasil yang diperoleh dalam penelitian.

Pelaksanaan terapi rendam air hangat dilakukan dengan menyiapkan air panas yang telah dicampur dengan air biasa sebanyak 2 liter hingga suhu mencapai $40^{\circ} \mathrm{c}$ (dapat ditoleransi oleh lansia). Pada kelompok perlakuan dengan penambahan garam dimasukkan garam sebanyak $20 \mathrm{mg}$ (3 sendok teh) lalu memasukan dan merendam kedua kaki lansia selama 15 menit. Pengukuran skala nyeri sebelum dan setelah diberikan perlakuan dengan menggunakan Numeric Rating Scale, rentang angka 0 sampai 10.

\section{HASIL DAN PEMBAHASAN \\ Hasil Univariat \\ Skala Nyeri Lansia Dengan Arthritis Sebelum Dilakukan Rendam Air Hangat}

Hasil analisis Skala Nyeri Lansia Dengan Arthritis Sebelum Dilakukan Rendam Air Hangat dapat dilihat pada tabel 1. 
Mursidah Dewi et al, Efektifitas Terapi Rendam Air Hangat dengan Garam terhadap Skala Nyeri Arthritis Pada Lansia Di Panti Sosial Tresna Werdha Budi Luhur Kota Jambi

Tabel 1. Analisis Skala Nyeri Lansia Dengan Arthritis Sebelum Dilakukan Rendam Air Hangat di PSTW Budi Luhur Kota Jambi Tahun $2019(n=30)$.

\begin{tabular}{lcccccc}
\hline \multicolumn{1}{c}{ Variabel } & n & Mean & Median & SD & Min-Maks & 95\% CI \\
\hline Skala nyeri & & & & & & \\
Air hangat+garam & 15 & 3,33 & 3,00 & 0,724 & $2-4$ & $2,93-3,73$ \\
Air hangat & 15 & 3,40 & 3,00 & 0,507 & $3-4$ & $3,12-3,68$ \\
\hline
\end{tabular}

Sumber: Data diolah

Analisis hasil penelitian pada tabel 1 menunjukkan bahwa rerata skala nyeri responden kelonpok sebelum dilakukan terapi air hangat+garam adalah 3,33 dengan 95\% CI : (2,93-3,73), median 3,00, dengan standar deviasi 0.72 . Skala nyeri terendah adalah 2 dan tertinggi adalah 4. Hasil estimasi interval diatas diketahui bahwa $95 \%$ diyakini bahwa rerataskala nyeri responden diantara 2,93 sampai dengan 3,73 dan tidak berdistribusi normal.

Pada kelompok responden sebelum dilakukan terapi air hangat tanpa garam didapatkan bahwa rerata skala nyeri responden sebelum dilakukan terapi air hangat adalah 3,40 dengan $95 \% \mathrm{CI}:(3,12-3,68)$, median 3,00 , dengan standar deviasi 0.507 . Skala nyeri terendah adalah 3 dan tertinggi adalah 4 . Hasil estimasi interval diatas diketahui bahwa $95 \%$ diyakini bahwa rerataskala nyeri responden diantara 3,12 sampai dengan 3,68.

\section{Skala Nyeri Lansia Dengan Arthritis Setelah Dilakukan Rendam Air Hangat}

Hasil analisis Skala Nyeri Lansia Dengan Arthritis Setelah Dilakukan Rendam Air Hangat dapat dilihat pada tabel 2 .

Tabel 2. Analisis Skala Nyeri Lansia Dengan Arthritis Setelah Dilakukan Rendam Air Hangat di PSTW Budi Luhur Kota Jambi Tahun $2019(n=30)$.

\begin{tabular}{lcccccc}
\hline \multicolumn{1}{c}{ Variabel } & n & Mean & Med & SD & Min-Maks & 95\%CI \\
\hline Skala nyeri & & & & & & \\
Air hangat+garam & 15 & 1,67 & 2,00 & 0,617 & $1-3$ & $1,32-2,01$ \\
Air hangat & 15 & 2,87 & 3,00 & 0,516 & $2-4$ & $2,58-3,15$ \\
\hline
\end{tabular}

Sumber: Data diolah

Analisis hasil penelitian pada tabel 2 menunjukkan bahwa rerata skala nyeri responden setelah dilakukan terapi air hangat+garam adalah 1,67 dengan 95\% CI : $(1,32-2,01)$, median 2,00, dengan standar deviasi $0.617 \%$. Skala nyeri terendah adalah 1 dan tertinggi adalah 3. Hasil estimasi interval diatas diketahui bahwa 95\% diyakini bahwa rerataskala nyeri responden diantara 1,32 sampai dengan 2,01 dan tidak berdistribusi normal.

Pada kelompok terapi rendam air hangat tanpa garam diketahui bahwa rerata skala nyeri responden setelah dilakukan terapi rendam air hangat adalah 2,87.
Skala nyeri terendah adalah 2 dan tertinggi adalah 4 . Hasil estimasi interval diatas diketahui bahwa 95\% diyakini bahwa rerataskala nyeri responden diantara 2,58 sampai dengan 3,15 .

\section{Hasil Bivariat}

Skala Nyeri Sebelum Dan Sesudah Dilakukan Rendam Air Hangat Dengan Garam Pada Lansia Dengan Arthritis

Perbedaan skala nyeri sebelum dan sesudah dilakukan rendam air hangat dengan garam pada lansia dengan Arthritis dijelaskan pada tabel 3.

Tabel 3. Analisis Skala Nyeri Sebelum Dan Sesudah Dilakukan Rendam Air Hangat Dengan Garam $(n=15)$

\begin{tabular}{llrrr}
\hline Variabel & & N & Mean Rank & Sum of Ranks \\
\hline Setelah air hangat + garam -sebelum air & Negative Ranks & $15^{\text {a }}$ & 8,00 & 120,00 \\
hangat +garam & Positive Ranks & $0^{\text {b }}$ & 0,00 & 0,00 \\
& Ties & $0^{\text {c }}$ & & \\
\hline & Total & 15 & \\
\hline
\end{tabular}

Sumber: Data diolah

Tabel 3 menunjukkan bahwa seluruh responden yang diberikan terapi rendam air hangat dengan garam (15 responden) mengalami penurunan skala nyeri. perubahan rerata skala nyeri sebelum dan setelah intervensi yaitu sebesar 1,66.
Skala Nyeri Sebelum Dan Sesudah Dilakukan Rendam Air Hangat Tanpa Garam Pada Lansia Dengan Arthritis 
Mursidah Dewi et al, Efektifitas Terapi Rendam Air Hangat dengan Garam terhadap Skala Nyeri Arthritis Pada Lansia Di Panti Sosial Tresna Werdha Budi Luhur Kota Jambi

Tabel 4. Analisis Skala Nyeri Sebelum Dan Sesudah Dilakukan Rendam Air Hangat Tanpa Garam Pada Lansia Dengan Arthritis di PSTW Budi Luhur Kota Jambi Tahun 2019 (n=15)

\begin{tabular}{lllrr}
\hline Variabel & & N & Mean Rank & Sum of Ranks \\
\hline Setelah air hangat - sebelum air hangat & Negative Ranks & $8^{\text {a }}$ & 4,50 & 36,00 \\
& Positive Ranks & $0^{\text {b }}$ & 0,00 & 0,00 \\
& Ties & $7^{\text {c }}$ & & \\
\hline & Total & 15 & \\
\hline
\end{tabular}

Sumber: Data diolah

Tabel 4 menunjukkan bahwa dari 15 orang responden terdapat 8 responden dengan selisih penurunan skala nyeri sebelum dan sesudah dilakukan rendam air hangat. 7 responden dengan skala nyeri yang sama sebelum dan sesudah terapi rendam air hangat tanpa garam.

\section{Perbedaan Rerata Skala Nyeri Sesudah Dilakukan Rendam Air Hangat Pada Kelompok Dengan Garam dan Kelompok Tanpa Garam Pada Lansia Dengan Arthritis}

Tabel 5. Analisis Perbedaan Skala Nyeri Sesudah Dilakukan Rendam Air Hangat Pada Kelompok Dengan Garam dan Kelompok Tanpa Garam Pada Lansia Dengan Arthritis di PSTW Budi Luhur Kota Jambi Tahun 2019.

\begin{tabular}{lr}
\hline & \multicolumn{2}{c}{ Skala Nyeri } \\
\hline $\mathrm{Z}$ & -4.249 \\
Asymp. Sig. (2-tailed) & .000 \\
\hline
\end{tabular}

Sumber: Data diolah

Dari Tabel 5 diketahui bahwa p-value yaitu $0,000<0,05$ maka terdapat perbedaan yang bermakna antara kedua terapi pada masing-masing kelompok yaitu kelompok rendam air hangat dengan garam dan kelompok rendam air hangat tanpa garam. Hasil estimasi diatas dapat disimpulkan bahwa ada perbedaan rerata skala nyeri setelah dilakukan terapi rendam air hangat dengan garam dengan terapi rendam air hangat tanpa garam

\section{Pembahasan}

Arthritis bisa dialami oleh semua golongan usia, termasuk remaja dan anak-anak. Namun, kondisi ini paling sering terjadi pada lansia terutama yang berusia di atas 65 tahun. Lansia merupakan kelompok usia yang rentan terhadap kesakitan akibat penurunan fungsi dalam tubuh. Anderson (2007) menyatakan faktor penuaan karena pertambahan usia seringkali disertai dengan timbulnya berbagai penyakit kronis seperti Arthritis, gangguan pendengaran, demensia, serta masalah jantung dan hipertensi sebagai penyakit yang terjadi pada sistem kardiovaskuler.

Arthritis adalah istilah umum untuk peradangan (inflamasi) dan pembengkakan pada satu atau lebih sendi dalam tubuh. Arthritis menggambarkan kumpulan gejala dengan banyak penyebab potensial. Nyeri dan kekakuan adalah gejala universal Arthritis yang paling banyak. Terdapat lebih dari 100 macam penyakit peradangan yang mempengaruhi daerah sekitar sendi, yang paling banyak adalah Osteoarthritis (OA), Arthritis gout (pirai), Arthritis rheumatoid (AR), dan fibromialgia. Gejala klinis yang sering adalah rasa sakit, ngilu, kaku, atau bengkak di sekitar sendi. Arthritis dapat mempengaruhi bagian lain dari tubuh; menyebabkan rasa sakit, kehilangan kemampuan bergerak dan kadang bengkak (Driskell, 2006; Mctaggart, 2016).

Zelman (2019) menuliskan tujuan pengobatan Arthritis adalah untuk meredakan rasa sakit, meningkatkan mobilitas dan kekuatan sendi, dan mengendalikan penyakit seefektif mungkin. Alternatif pengobatan terdiri dari penggunaan obat-obatan farmakologis, olahraga, kompres panas/dingin, penggunaan pelindung sendi, dan operasi.

Keluhan terkait gangguan persendian adalah nyeri, yang menjadi keluhan utama pada lansia. Penatalaksanaan nyeri secara nonfarmakologi, terdiri atas berbagai strategi penatalaksanaan nyeri fisik dan kognitif perilaku. Intervensi fisik mencakup stimulasi kutaneus, imobilisasi, stimulasi saraf elektrik transkutan (TENS), dan akupuntur (Kozier, B et al, 2010). Menurut Potter \& Perry (2010) teknik stimulasi kutaneus terdiri dari pijat, aplikasi panas dingin, akupresur dan immobilisasi. Aplikasi panas/dingin merupakan salah satu bentuk penatalaksanaan pada Arthritis untuk mengurangi rasa sakit dan nyeri.

Pada kegiatan penelitian ini, Aplikasi panas/dingin sebagai salah satu penatalaksanaan nyeri dilakukan dengan cara terapi rendam air hangat, dengan melakukan dua perlakuan terapi pada dua kelompok lansia dengan Arthritis, yaitu terapi rendam air hangat dengan penambahan garam pada kelompok pertama dan terapi rendam air hangat tanpa garam pada kelompok kedua. Tujuan penelitian ini adalah untuk mengetahui efektifitas terapi rendam air hangat dengan garam terhadap skala nyeri lansia dengan Arthritis di Panti Sosial Tresna Werdha Budi Luhur Kota Jambi. Secara rinci hasil penelitian akan dibahas sebagai berikut :

Skala Nyeri Arthritis pada Lansia Sebelum Dilakukan Terapi Rendam Air Hangat 
Nyeri adalah suatu hal yang bersifat subjektif, tidak ada dua orang sekalipun yang mengalami kesamaan rasa nyeri dan tidak ada dua kejadian menyakitkan yang mengakibatkan respons atau perasaan yang sama pada individu. Nyeri didefinisikan sebagai sesuatu yang tidak menyenangkan, bersifat subjektif dan berhubungan dengan panca indera, serta merupakan suatu pengalaman emosional yang dikaitkan dengan kerusakan jaringan baik aktual maupun potensial, atau digambarkan sebagai suatu kerusakan/cidera. Nyeri terjadi dalam berbagai derajat keparahan, baik akut maupun kronis, walaupun tidak menyenangkan, nyeri merupakan bagian komponen utama sistem saraf, menginstruksikan neuron motorik dari sistem saraf pusat sebagai deteksi adanya kerusakan fisik. (Potter \& Perry, 2010; Amudha, 2014, Benita, 2016).

Hasil penelitian menunjukkan rerata skala nyeri Lansia sebelum dilakukan terapi air hangat pada kelompok tanpa penambahan garam adalah 3,40. Skala nyeri terendah adalah 3 dan tertinggi adalah 4. Hasil estimasi interval diatas diketahui bahwa $95 \%$ diyakini bahwa rerataskala nyeri responden diantara 3,12 sampai dengan 3,68. Pada kelompok lansia dengan terapi rendam air hangat dengan garam didapatkan bahwa rerata skala nyeri Lansia adalah 3,33. Skala nyeri terendah adalah 2 dan tertinggi adalah 4 . Hasil estimasi interval pada penelitian ini diketahui bahwa 95\% diyakini bahwa rerata skala nyeri responden diantara 2,93 sampai dengan 3,73.

Keluhan nyeri pada Arthritis ditemukan pada sebagian besar jenis Arthritis. Pada Arthritis Gout adanya deposit kristal asam urat pada sinovial/rongga sendi akan mengakibatkan terjadinya inflamasi. Pada Rhematoid Arthritis nyeri bersifat persisten yaitu rasa nyeri yang hilang timbul. Rasa nyeri akan menambahkan keluhan mudah lelah dan gangguan saat beraktivitas. Nyeri Rhematoid Arthritis terjadi pada sendi-sendi tangan dan kaki, selain itu sendi bahu, panggul, dan tulang belakang terutama servikal. Pada pria, lebih sering bermanifestasi pada sendi-sendi besar. $73 \%$ Rheumatoid Arthritis pada pria akan bersifat erosif (55\% pada wanita). Pada wanita lebih sering menjalani operasi orthopaedi (pria : wanita $=1: 2$ ) (Fauzi.A, 2019). Secara umum, kondisi nyeri yang ada pada berbagai jenis Arthritis membutuhkan perawatan dalam jangka waktu yang lama, bertujuan meningkatkan kualitas hidup lansia.

\section{Skala Nyeri Arthritis pada Lansia Sesudah Dilakukan Terapi Rendam Air Hangat}

Salah satu bentuk penatalaksanaan Arthritis yang penting adalah manajemen perawatan diri yang efektif. Perawatan diri pada penderita Arthritis dapat dilakukan dengan pemanfaatan air hangat. Rendam hangat adalah tindakan yang dilakukan dengan memberikan cairan hangat untuk memenuhi kebutuhan rasa nyaman, mengurangi atau membebaskan nyeri, mengurangi atau mencegah terjadinya spasme otot, dan memberikan rasa hangat (Uliyah \& Hidayat 2008, Mendelson, McCullough \& Chan, 2010).

Pemberian rendam air air hangat adalah intervensi keperawatan yang sudah lama di aplikasikan oleh perawat, rendam air hangat dianjurkan untuk menurunkan nyeri karena dapat meredakan nyeri, meningkatkan relaksasi otot, meningkatkan sirkulasi, meningkatkan relaksasi psikologis, dan memberi rasa nyaman, bekerja sebagai counteriritan (Kozier, B et al, 2010)

Hasil penelitian menunjukkan bahwa rerata skala nyeri lansia pada kelompok terapi air hangat dengan garam adalah 1,67. Skala nyeri terendah adalah 1 dan tertinggi adalah 3. Pada kelompok kedua, setelah intervensi terapi air hangat tanpa garam dihasilkan rerata skala nyeri Lansia setelah dilakukan terapi air hangat adalah 2,87. Skala nyeri terendah adalah 2 dan tertinggi adalah 4 .

Berendam dalam air garam ternyata bisa membantu untuk mengatasi nyeri. Melakukan rendam larutan air garam hangat dapat mengurangi Skala nyeri pada bagian yang terkena asam urat. Dengan merendam bagian yang terkena asam urat, darah akan mengalir lebih lancar dan penggumpalan asam urat pada persendian juga akan berkurang. Garam mengandung beberapa zat kimia seperti unsur sodium dan natrium. Unsur sodium penting untuk mengatur keseimbangan cairan didalam tubuh, selain itu bertugas dalam transmisi saraf dan kerja otot. Panas dari garam akan menyedot toksin dalam tubuh sehingga dapat mengobati masuk angin dan memperlancar peredaran darah. Dibanding terapi panas yang lain, terapi garam panas memiliki sebuah keunggulan. Garam mampu menyimpan panas lebih lama sehingga selama perawatan panas garam tetap optimal (Nuraini, 2016).

Penelitian Nuridayanti (2017) tentang Pengaruh rendam air garam terhadap penurunan skala nyeri pada penderita gout di desa toyoresmi kecamatan gampengrejo kabupaten kediri dihasilkan ada pengaruh rendam air garam terhadap penurunan tingkat nyeri sebelum dan sesudah dilakukan rendam air garam. Melakukan rendam air garam hangat dapat mengurangi skala nyeri pada bagian yang terkena asam urat. Dengan merendam bagian yang terkena asam urat, darah akan mengalir lebih lancar dan penggumpalan asam urat pada persendian juga akan berkurang.

Dari hasil pengukuran skala nyeri setelah dilakukan rendam air hangat dengan garam maupun tanpa garam pada kedua kelompok lebih lanjut diketahui rerata skala nyeri lansia pada kelompok rendam air hangat dengan garam diantara 1,32 sampai dengan 2,01. Untuk kelompok rendam air hangat tanpa garam rerata skala nyeri lansia berada dalam rentang 2,58 sampai dengan 3,15. Skala nyeri yang dialami lansia dalam kategori nyeri ringan. 
Nyeri merupakan salah satu mekanisme pertahanan tubuh yang menandakan adanya masalah. Nyeri yang tidak ditangani menyebabkan bahaya fisiologis dan psikologis bagi kesehatan dan penyembuhan (Kozier, B, et al 2010). Terjadinya perubahan skala nyeri setelah dilakukan terapi rendam air hangat dengan garam, berdasarkan hasil pengukuran dan literatur penelitan yang ada dengan berkurangnya rasa nyeri dapat meningkatkan kenyamanan pasien baik secara fisiologis maupun psikososial. Merendam kaki, darah akan mengalir lebih lancar. Garam dengan kandungan unsur sodiumnya penting untuk mengatur keseimbangan cairan didalam tubuh, selain itu bertugas dalam transmisi saraf dan kerja otot. Panas dari garam akan menyedot toksin dalam tubuh sehingga dapat memperlancar peredaran darah.

\section{Perbedaan Rerata Skala Nyeri Sesudah Dilakukan Rendam Air Hangat Pada Kelompok Dengan Garam dan Kelompok Tanpa Garam Pada Lansia Dengan Arthritis}

Hasil penelitian menunjukkan adanya perubahan rerata skala nyeri sebelum dan setelah terapi rendam air hangat dengan garam yaitu sebesar 1,66, perubahan rerata skala nyeri sebesar 0,53 dihasilkan pada kelompok lansia dengan terapi rendam air hangat tanpa penambahan garam. Lebih lanjut, hasil penelitian diketahui bahwa seluruh responden yang diberikan terapi rendam air hangat dengan garam mengalami penurunan skala nyeri setelah diberikan terapi rendam air hangat, Pada kelompok lansia dengan terapi rendam air hangat tanpa garam terdapat 8 responden dengan selisih penurunan skala nyeri, dan terdapat 7 responden dengan skala nyeri yang sama.

Perubahan rerata yang signifikan terjadi pada responden yang diberikan terapi rendam air hangat dengan garam sebesar 3,33-1,67 yaitu 1,66 dengan nilai (p-value $0,000<\mathrm{p} \alpha 0,05$ ), dan perubahan rerata terapi rendam air hangat tanpa garam sebesar 3,40-2,87 yaitu 0,53 dengan nilai ( $\mathrm{p}$-value $0,005<\mathrm{p} \alpha 0,05$ ), dengan perbedaan rerata keduanya yaitu sebesar 1,13 . Hasil uji stasistik menunjukkan bahwa p-value yaitu $0,000<0,05$, terdapat perbedaan yang signifikan rerata skala nyeri pada terapi rendam air hangat dengan garam dengan terapi rendam air hangat tanpa garam pada lansia dengan Arthritis dengan p-value sebesar 0,000.

Dari hasil penelitian ini, diketahui bahwa intervensi yang dilakukan dengan terapi rendam air hangat pada lansia yang mengalami nyeri Arthritis baik itu dengan penambahan garam maupun tanpa garam dapat mengurangi rasa nyeri pada lansia. Perubahan skala nyeri terbesar dihasilkan pada terapi rendam air hangat dengan penambahan garam.

Benita, R.F (2016) dalam penelitiannya tentang efektivitas penggunaan air panas yang diaplikasikan dengan panambahan garam dalam mengurangi nyeri sendi pasien lansia dengan Rheumatoid Arthritis dihasilkan ada perbedaan yang signifikan pre dan post tes skor nyeri pada pasien Lansia dalam kelompok eksperimen $(\mathrm{p}=0,001)$. Dari hasil penelitian ini, disimpulkan bahwa penggunaan air panas dengan garam efektif dalam mengurangi nyeri sendi Rheumatoid Arthritis pada Lansia. Peneliti merekomendasikan, penatalaksanaan air panas dengan garam penting dilakukan untuk untuk mengurangi rasa sakit Rheumatoid Arthritis pada Lansia.

Garam mengandung beberapa zat kimia seperti unsur sodium dan natrium. Unsur sodium penting untuk mengatur keseimbangan cairan didalam tubuh, selain itu bertugas dalam transmisi saraf dan kerja otot. Panas dari garam akan menyedot toksin dalam tubuh sehingga dapat memperlancar peredaran darah. Dibanding terapi panas yang lain, terapi garam panas memiliki sebuah keunggulan. Garam mampu menyimpan panas lebih lama sehingga selama perawatan panas garam tetap optimal (Nuraini, 2016)

Lebih lanjut, Ramsay (2014) dalam Amudha (2014) memaparkan manfaat garam yang digunakan dalam terapi air hangat. Garam Epsom, salah satu jenis garam yang tinggi magnesium, bermanfaat dalam membantu meringankan nyeri sendi, dapat dilakukan sebelum tidur, dengan cara melarutkan tiga cup garam Epsom ke dalam air panas, Rendam kain bersih dalam air panas dan buat kompres, kompres pada sendi lutut selama 10 hingga 15 menit, sambil secara perlahan menggrakkan sendi dan Otot-otot, terapi ini akan membantu meredakan nyeri sendi lutut.

Sejalan dengan penelitian Amudha (2014), terjadi penurunan nyeri sebesar $58 \%$ pada kelompok eksperimen dengan perlakuan kompres air hangat dengan garam dibandingkan kelompok kontrol yang mengalami penurunan nyeri hanya sebesar $3 \%$. Kondisi ini ditemukan dalam penelitian yang dilakukannya yaitu efektifitas kompres air panas dengan garam untuk meredakan nyeri sendi lutut pada wanita lansia di Chennai. Pemanfaatan terapi ini lebih ekonomis, dapat diterima oleh masyarakat, aman dilakukan sendiri dirumah, hampir tidak ada efek samping dibandingkan dengan terapi fharmakologis.

Pendidikan kesehatan merupakan komponen penting dalam penatalaksanaan suatu penyakit, termasuk Arthritis (Baluni, 2014). Perawatan Arthritis banyak yang bersifat mandiri, motivasi dan inisiatif pasien menjadi komponen penting. Pendidikan kesehatan yang diberikan dapat berupa penjelasan tentang pentingnya penatalaksanaan penyakit dan perawatan nonfarmakologis, seperti manajemen nyeri nonfarmakologis, kemampuan pemecahan masalah, dan prinsip-prinsip melindungi sendi dari cedera serta aktivitas fisik yang sesuai.

Meningkatkan dan mempertahankan kondisi kesehatan lansia untuk dapat berfungsi sesuai dengan kemampuannya, memfasilitasi kebutuhan lansia, membantu lansia dalam menyelesaikan permasalahannya 
merupakan upaya yang dapat dilakukan oleh fasilitas pelayanan kesehatan maupun lembaga pemerintahan termasuk panti sosial lansia (Palmer, S,D. 2011). Dalam lingkungan panti kegiatan pendidikan kesehatan terkait penatalaksanaan Arthritis dapat dilakukan oleh perawat dan tenaga kesehatan lain. Upaya dapat dilakukan dengan menyediakan bahan bacaan, pemanfaatan kegiatan terapi aktivitas kelompok, kegiatan olah raga/aktivitas fisik yang sesuai, serta penyuluhan kesehatan yang dilakukan secara individu maupun berkelompok, yang bertujuan untuk meningkatkan kemampuan lansia dalam perawatan dan pemeliharaan penyakit Arthritis.

Penulis berpendapat terapi rendam rendam air hangat dengan garam dapat dijadikan tindakan non farmakologi yang efektif untuk menurunkan nyeri, dari segi biaya terapi ini termasuk ekonomis, mudah untuk dilakukan secara mandiri maupun dengan pendampingan perawat serta aman. Seorang perawat yang berkecimpung dalam pengelolaan atau yang memberikan asuhan keperawatan Lansia harus memiliki kemampuan memahami perubahan degeneratif secara fisik dan psikososial pada lansia, mempunyai kompetensi klinis sebagai dasar dalam melakukan tindakan keperawatan (Ekasari, dkk 2018). Memaksimalkan peran mandiri perawat adalah bentuk keterlibatan perawat dalam meningkatkan kesehatan lansia dengan Arthritis.. Peran perawat tersebut diantaranya sebagai care provider terlihat dalam aktivitas perawat memberikan intervensi keperawatan, mendampingi lansia dalam pelaksanaan terapi, peran edukasi dalam memberikan pendidikan kesehatan tentang penatalaksanaan nyeri Arthritis, peran fasilitator dalam memfasilitasi lansia untuk melakukan terapi, serta peran kolaborator berkolaborasi dengan tim kesehatan lain yang ada di panti dalam penatalaksanaan nyeri Arthritis pada Lansia melalui intervensi keperawatan rendam air hangat dengan garam.

\section{SIMPULAN}

1. Rata-rata skala nyeri responden sebelum dilakukan terapi air hangat dengan garam adalah 3,33 dan ratarata skala nyeri responden setelah dilakukan terapi air hangat dengan garam adalah 1,67.

2. Rata-rata skala nyeri responden sebelum dilakukan terapi air hangat adalah 3,40 dan rata-rata rata-rata skala nyeri responden setelah dilakukan terapi air hangat+garam

3. Seluruh responden yang diberikan terapi rendam air hangat dengan garam mengalami penurunan skala nyeri. perubahan rerata skala nyeri sebelum dan setelah intervensi yaitu sebesar 1,66.

4. Skala nyeri pada lansia dengan Arthritis sebelum dan setelah diberikan terapi rendam air hangat tanpa garam menunjukkan bahwa dari 15 responden, 8 responden mengalami selisih penurunan skala nyeri, dan 7 responden dengan skala nyeri yang sama.
5. Hasil uji stasistik menunjukkan, terdapat perbedaan yang signifikan rerata skala nyeri pada terapi rendam air hangat dengan garam dengan terapi rendam air hangat tanpa garam pada lansia dengan Arthritis ( $\mathrm{p}$ value $0,000<\mathrm{p} \alpha 0,05)$.

6. Hasil penelitian menunjukkan terapi rendam air hangat dengan garam lebih efektif diberikan untuk mmenurunkan skala nyeri pada lansia dengan Arthritis.

\section{DAFTAR PUSTAKA}

Agoes, H.A (2011). Penyakit Di usia Tua. Penerbit Buku Kedokteran EGC, Jakarta : 248.

Amudha (2014). Assess The Effectiveness of Hot Water Compress With Epsom Salt Among Elderly Women With Knee Joint Pain Residing at Selected Urban Area Choolai in Chennai. A Dissertation. Madras Medical College, Chennai.

Anderson, ET \& McFarlane, JM (2011). Community as Partner : Theory and Practice in Nursing. Sixth edition, Philadelphia: Wolters Kluwer Health/Lippincott Williams \& Wilkins.

Anderson, M.A (2007). Caring For Older Adults Holistically. Philadelphia: F.A. Davis Company.

Arikunto, S. (2010). Prosedur Penelitian Suatu Pendekatan Praktik. Jakarta:Rineka Cipta.

Baluni, S (2014). A Review : Possible Approaches For Evaluating Arthritis And Its Management. International Journal of Innovative Research and Advanced Studies (IJIRAS), Volume 1 Issue 2, December 2014 : 5-13.

Benita, RF (2016). A Study to Assess The Effectiveness of Hot Water Application With Epsom Salt in Reducing Joint Pain Among Old Age Patients With Rheumatoid Arthritis in a Selected Hospital At Coimbatore. A Dissertation. Ellen college of nursing, Coimbatore.

Dahlkemper, TR (2016). Caring For Older Adults Holistically. Sixth Edition. Philadelphia : F.A. Davis Company.

Dewi, S.R. (2014). Buku ajar keperawatan gerontik. Yogyakarta: Deepublish.

Driskell (2006). What You Need to Know About Arthrits. American Physical Therapy Association

Ekasari, dkk, (2018). Meningkatkan Kualitas Hidup Lansia : Konsep dan berbagai strategi intervensi. Malang: Wieneka Media

Fauzi, A (2019). Rheumatoid Arthritis. JK Unila. Volume 3. Nomor 1. Dari http://repository.lppm.unila.ac.id/16093/1/JK.\%20 Unila\%20\%28dr.\%20A.\%20Fauzi\%29.pdf

Kemenkes, RI (2013). Gambaran Kesehatan Lanjut Usia di Indonesia. Buletin Jendela Data dan Informasi Kesehatan, Kementerian Kesehatan RI. 2013; Semester I, 2013:1-18. 
Kemenkes, RI (2016). Situasi Lanjut Usia (Lansia) di Indonesia. Pusat data dan informasi Kementerian Kesehatan RI.

Kemenkes, RI (2016). Hasil Utama Riskesdas 2018. Badan Penelitian dan Pengembangan Kesehatan.

Kozier, B. et al (2010). Buku Ajar Fundamental Keperawatan. Edisi 7 Volume 1. Jakarta : EGC

Mctaggart (2016). Arthritis: Drug-Free Alternatives to Prevent and Reverse Arthritis (What Doctors Don't Tell You). WDDTY Publishing Ltd. Canada : Richmont BT.

Mendelson, C. McCullough \& Chan (2010). Integrating Self-Management and Exercise For People Living With Arthritis. Health Education Research. Feb;26(1):167-77.

Muhith, H \& Siyoto, S. (2016). Pendidikan Keperawatan Gerontik. Yogyakarta : Andi Offset

Nuraini D.N (2016). Sehat Dengan Diet dan Terapi Garam, Jakarta : Gosye Publishing.

Nuridayanti (2017). Pengaruh Rendam Air Garam Terhadap Penurunan Tingkat Nyeri pada Penderita Gout di Desa Toyoresmi Kecamatan Gampengrejo Kabupaten Kediri. Jurnal Kesehatan, Vol. 1 No. 2, Juli - Desember 2017 : 116-121

Palmer, SD (2011). Social Work And Geriatric Services. Canada : Apple Academic Pres, Inc

Peraturan Menteri Kesehatan RI (2016). Rencana Aksi Nasional Kesehatan Lanjut Usia Tahun 20162019. PMK No. 25. Jakarta

Potter \& Perry (2010). Buku Ajar Fundamental Keperawatan. Edisi 7. Jakarta : Salemba Medika

Riyanto, A (2011). Aplikasi Metodologi Penelitian Kesehatan. Yogyakarta : Nuha Medika

Soeroso, J \& Algristian, H (2011). Asam Urat. Penebar Plus. Cetakan ke-1. Jakarta : Niaga Swadaya

Suriya, M (2016). Efektifitas Rendam Air Air Hangat Terhadap Penurunan Nyeri Pada Pasien Asam Urat Di Puskesmas Lubuk Begalung. Ejournal Annurpurwodadi. Dari http://ejournal.annurpurwodadi.ac.id/index.php/TS CS1Kep/article/viewFile/72/80

Uliyah \& Hidayat (2008) Praktikum Keterampilan Dasar Praktik Klinik: Aplikasi Dasar-dasar Praktik Kebidanan, Jakarta : Salemba Medika

Zelman (2019). Arthritis Pain Management. WebMD Medical Reference, dari https://www.webmd.com/Arthritis/pain$\underline{\text { management-Arthritis\#3 }}$ 